\title{
Microcystin Content in Phytoplankton and in Small Fish from Eutrophic Nyanza Gulf, Lake Victoria, Kenya
}

\author{
Benard Mucholwa Simiyu ${ }^{1,2}$, Steve Omondi Oduor ${ }^{2}$, Thomas Rohrlack ${ }^{3}$, Lewis Sitoki ${ }^{4}$ \\ and Rainer Kurmayer 1,* (iD) \\ 1 Research Department for Limnology, University of Innsbruck, Mondseestrasse 9, 5310 Mondsee, Austria; \\ bmucholwa@gmail.com \\ 2 Department of Biological Sciences, Egerton University, P.O. Box 536, Egerton 20115, Kenya; \\ soduor@egerton.ac.ke \\ 3 Environmental Sciences, Norwegian University of Life Sciences (NMBU), 1430 As, Norway; \\ thomas.rohrlack@nmbu.no \\ 4 Department of Geosciences and the Environment, The Technical University of Kenya, P.O. Box 52428, \\ Nairobi 00200, Kenya; sitoki@hotmail.com \\ * Correspondence: rainer.kurmayer@uibk.ac.at; Tel.: +43-512-507-50242
}

Received: 23 April 2018; Accepted: 2 July 2018; Published: 3 July 2018

\begin{abstract}
The human health risks posed by exposure to cyanobacterial toxins such as microcystin (MC) through water and fish consumption remain poorly described. During the last two decades, coastal regions of Lake Victoria such as Nyanza Gulf (Kisumu Bay) have shown severe signs of eutrophication with blooms formed by Microcystis producing MC. In this study, the spatial variability in MC concentration in Kisumu Bay was investigated which was mostly caused by Microcystis buoyancy and wind drifting. Small fish $(<6 \mathrm{~cm})$ mainly composed of Rastrineobola argentea were examined for MC content by means of biological methods such as ELISA and protein phosphatase inhibition assay (PPIA) and partly by chemical-analytical methods such as LC-MS/MS. Overall, the MC content in small fish was related to the MC content observed in the seston. When comparing the MC content in the seston in relation to dry weight with the MC content in small fish the latter was found three orders of magnitude decreased. On average, the ELISA-determined MC contents exceeded the PPIA-determined MC contents by a factor of $8.2 \pm 0.5$ (SE) while the MC contents as determined by LC-MS/MS were close to the detection limit. Using PPIA, the MC content varied from 25-109 (mean $62 \pm 7$ ) $\mathrm{ng} / \mathrm{g}$ fish dry weight in Kisumu Bay vs. $14 \pm 0.8 \mathrm{ng} \mathrm{MC} / \mathrm{g}$ in the more open water of L. Victoria at Rusinga channel. Drying the fish under the sun showed little effect on MC content, although increased humidity might indirectly favor photocatalyzed MC degradation.
\end{abstract}

Keywords: eutrophication; Microcystis; spatial variability; cyanotoxins; ELISA; PPIA; food chain; Rastrineobola argentea

Key Contribution: MC contents were determined in phytoplankton and in small fish consumed as a whole using two independent methods ELISA and PPIA in parallel and were found biodiluted by three orders of magnitude.

\section{Introduction}

Lake Victoria has experienced major deterioration in its water quality mainly due to pollution and the introduction of exotic species [1]. The increased eutrophication is associated with urbanization, agricultural malpractices and deforestation [2]. Nutrients enter the lake from both point sources [1] 
and diffuse sources, including atmospheric deposition [3], which has exerted a considerable impact on the near shore areas $[2,4]$.

Nyanza Gulf is one of the bays of Lake Victoria that is most affected by nutrient enrichment [5] which is coming from the highly populated catchment with mostly subsistence agriculture $[2,6]$. This has led to regular occurrence of bloom-forming cyanobacteria [7]. Some cyanobacterial species have the potential to produce cyanotoxins that pose a health risk to livestock and humans who rely on such water for drinking, sanitation, or as a food source [8]. The regular occurrence of cyanobacterial blooms in the Nyanza Gulf has been associated with fish kills and temporary shutdown of drinking water supply, i.e., from January to March 2004 [9].

The harmful cyanobacteria form surface scums due to a combination of buoyancy in the cells and wind action [10]. The buoyancy is caused by intracellular gas vesicles that decrease the specific density of the cells and is enhanced by cells forming large aggregates known as colonies. The diameter of the colonies can be several millimeters resulting in a rising of the cells up to the calm water surface within minutes [11]. These scums are also accumulated by wind action at the water surface which may result in the accumulation of cyanotoxins several orders of magnitude higher compared with the depth-integrated average concentrations [10]. The most common cyanotoxins are the hepatotoxic microcystins (MC) produced by cyanobacteria such as Microcystis, Dolichospermum (Anabaena), Planktothrix (Oscillatoria) and Nostoc [8]. The toxicity of MC is based on the potent inhibition of the protein phosphatases, PP1 and PP2a, disturbing cytoskeleton formation in eukaryotic cells. The oral $\mathrm{LD}_{50}$ for MC-LR in rats is $5 \mathrm{mg}$ per $\mathrm{kg}$ of body weight that is comparable to the toxicity of cyanide [12]. Chronic MC exposure may promote tumor formation and has been linked to cancer development [13]. The colony-forming cyanobacteria such as Microcystis and Dolichospermum are most frequent in the Lake Victoria region and Microcystis is most frequently occurring in turbid and eutrophic water bodies [14]. It was shown that in Ugandan freshwater systems, the genus Microcystis rather than Dolichospermum or other genera produce MC [15].

$\mathrm{MC}$ is transferred through feeding from the cyanobacteria to zooplankton, fish and other aquatic biota and even to higher trophic levels [16-18]. Phytoplanktivouros fish such as filter-feeding Oreochromis niloticus are exposed to MC by unselective ingestion of toxic cyanobacterial cells [19]. In contrast, zooplanktivorous and carnivorous fish show a more direct feeding mode and could be exposed to cyanotoxins via trophic transfer [20]. On the other hand, even juvenile Oreochromis niloticus and smaller fish feeding more selectively on zooplankton in Murchison Bay, Lake Victoria, were observed to ingest toxic cyanobacteria along with detritus [21]. The occurrence of MC in fish tissue sampled from East African Lakes (including Lake Mburo, Napoleon Gulf and Murchison Bay of L. Victoria) has been demonstrated previously $[19,22,23]$. In order to assess human exposure risk, Poste et al. [23] pointed out the need to consider potential exposure to MC through fish consumption. These authors tested a variety of different fish species differing in feeding modes, including filter feeders, carnivorous feeders and small (juvenile) zooplanktivorous fish species. In contrast to large fish species where dorso-lateral fish muscle tissue was analyzed, the small fish $(<10 \mathrm{~cm})$ were analyzed in total. In this study, [23] the total MC concentrations were estimated by ELISA sometimes exceeding the Total Daily Intake (TDI) guideline $(0.04 \mu \mathrm{g} / \mathrm{kg}$ body weight assuming a consumption of $100 \mathrm{~g}$ of fish daily) several fold [24]. The highest MC concentrations were determined in small (juvenile) zooplanktivorous fish such as Haplochromis spp. and the silver cyprinid Rastrineobola argentea, which could have resulted from the inclusion of toxic cyanobacteria in the gut. Commercial fishing for $R$. argentea started in the 1980s and today is considered the most important fishery by mass in the Lake Victoria region [25]. Small fish such as R. argentea are popular food around Lake Victoria and are marketed locally by women providing a cheap source of animal protein for the undernourished population [26,27]. These small fish are caught during the night using light traps and dried in the sun between 6 and $8 \mathrm{~h}$ the following day. Since the small fish are eaten as a whole, a transfer of MC to humans seems more likely when compared with fish muscle tissue consumption. It is known that MC cannot be degraded by sunlight alone. Indeed, the rate of MC degradation in 
the light depends on several factors such as wavelength (UV), $\mathrm{pH}$ and the presence of pigments or photocatalysts [12]. Because the small fish are dried in the sun for several hours, the exposure to sunlight might enable a breakdown of MC because ingested and lysing cyanobacterial cells in the gut would release photopigments as well. This study aimed to (i) quantify MC content in the locally consumed small fish in relation to the MC concentration in phytoplankton, and (ii) establish whether the processing of fish through drying in the sunlight has an effect on the final MC content in the fish. Fish sampled from inside the eutrophic Nyanza Gulf (ST1) near Kisumu were compared with fish sampled from Rusinga Channel located close to the main basin (ST2), that is less affected by eutrophication and MC contamination [9].

\section{Results}

\subsection{Spatial Variation of Physical-Chemical Parameters}

Over the entire study period, at ST1 (near Kisumu) the lake water was found to be rather turbid with low transparency $(<26 \mathrm{~cm}$ ). In contrast, at ST2 (close to the main basin) higher water transparency was recorded $(85 \mathrm{~cm})$. At ST1 higher conductivity was recorded while temperature and $\mathrm{pH}$ showed no variation between ST1 and ST2 (Table 1). For chlorophyll $a$, relatively low concentrations were recorded from the depth-integrated water samples both at ST1 $(10-30 \mu \mathrm{g} / \mathrm{L})$ and at ST2 in the main basin. Higher concentrations occurred at ST1 at the surface $(19-50 \mu \mathrm{g} / \mathrm{L})$, while maximum concentrations were recorded from the patches $(274-4382 \mu \mathrm{g} / \mathrm{L})$ forming bands possibly formed by Langmuir movements (Supplementary Figure S1). High chlorophyll $a$ concentrations were also observed at the shore $(18-1737 \mu \mathrm{g} / \mathrm{L})$. 
Table 1. Physicochemical and biological variables (mean \pm SE) during the study period (October 2011 to January 2012).

\begin{tabular}{|c|c|c|c|c|c|c|c|c|c|c|c|c|}
\hline \multirow{2}{*}{ Date } & \multirow{2}{*}{ Temp. $\left({ }^{\circ} \mathrm{C}\right)$} & \multirow{2}{*}{ Cond. $(\mu \mathrm{S} / \mathrm{cm})$} & \multirow{2}{*}{$\mathrm{pH}$} & \multirow{2}{*}{ Secchi (cm) } & \multicolumn{4}{|c|}{ Chlorophyll $a(\mu \mathrm{g} / \mathrm{L})$} & \multicolumn{4}{|c|}{ Total Phytoplankton Biovolume $\left(\mathrm{mm}^{3} / \mathrm{L}\right)$} \\
\hline & & & & & Surface & Integrated & Patch & Shore & Surface & Integrated & Patch & Shore \\
\hline \multicolumn{13}{|c|}{ Kisumu Bay (ST1) } \\
\hline 27 October 2011 & $25.3 \pm 0.1$ & $153 \pm 0.4$ & $6.5 \pm 0.3$ & 25 & 50 & 14 & 1038 & 128 & 3.5 & 3.9 & 22.4 & 3.7 \\
\hline 8 November 2011 & n.d & $159 \pm 0.1$ & $6.3 \pm 0.2$ & 15 & 20 & 17 & 274 & 18 & 2.4 & 2.1 & 264 & 1.6 \\
\hline 5 December 2011 & $24.9 \pm 0.3$ & $130 \pm 0.3$ & $6.5 \pm 0.1$ & 27 & 19 & 10 & 845 & 73 & 5.0 & 3.0 & 145 & 34 \\
\hline 10 January 2012 & $25.5 \pm 0.2$ & $134 \pm 0.3$ & n.d & 7 & 44 & 30 & 4382 & 1737 & 7.3 & 4.5 & 2467 & 291 \\
\hline \multicolumn{13}{|c|}{ Rusinga Channel (ST2) } \\
\hline 9 January 2012 & $25.8 \pm 0.1$ & $106 \pm 0.1$ & n.d & 85 & 13 & 14 & $\mathrm{n} / \mathrm{a}$ & 15 & 2.2 & 2.6 & $\mathrm{n} / \mathrm{a}$ & 3.0 \\
\hline
\end{tabular}




\subsection{Phytoplankton Composition}

Phytoplankton composition was dominated by Cyanobacteria, Bacillariophyceae, Cryptophyceae, and Chlorophyceae; however, all groups occurred with relatively few taxa only. Cyanobacteria were composed mainly of the genera Microcystis, Planktolyngbya and Dolichospermum (Anabaena) at both ST1 and ST2. The Bacillariophyceae, Cryptophytes and Chlorophytes were dominated by Nitzschia, Cryptomonas and Chlamydomonas, respectively (Supplementary Table S1).

The cyanobacteria dominated in all depth-integrated samples at ST1 and ST2. Typically, this dominance was due to the abundance of Microcystis (54 \pm (SE) 10\%) and Planktolyngbya $(20 \pm 8 \%)$. When compared with depth-integrated samples, the proportion of Microcystis increased significantly in patch $(98 \pm 2 \%)$ and shore $(80 \pm 7 \%)$ samples (Repeated Measures ANOVA on Ranks, $p<0.001$, Tukey test for post-hoc pairwise multiple comparison, $p<0.05)$. In contrast, a decrease in proportion of Planktolyngbya in patch $(1 \pm 1 \%)$ and shore $(5 \pm 3 \%)$ samples was found (Repeated Measures ANOVA on Ranks, $p \leq 0.001$, Tukey test $p<0.05$ ). The patch and shore samples also showed maximum phytoplankton biovolume that differed from depth-integrated samples on average by an order of magnitude (Figure 1). In contrast, the changes in phytoplankton composition at the surface of the water column were less visible. The Bacillariophyceae contributed the second most abundant algal class, most importantly by the genus Nitzschia. The proportion of Nitzschia decreased when comparing depth-integrated $(13 \pm 6 \%)$ samples with patch $(1 \pm 1 \%)$ and shore $(2 \pm 1 \%)$ samples (Repeated Measures ANOVA on Ranks, $p=0.002$, Tukey test $p<0.05$ ). In summary, the general dominance of Microcystis in phytoplankton became even more pronounced among patch and shore samples. There was a positive correlation between the two phytoplankton biomass estimates, phytoplankton biovolume and chlorophyll $a$ concentrations $\left(\mathrm{R}^{2}=0.81, p<0.001\right)$, (Supplementary Figure $\mathrm{S} 2$ ).

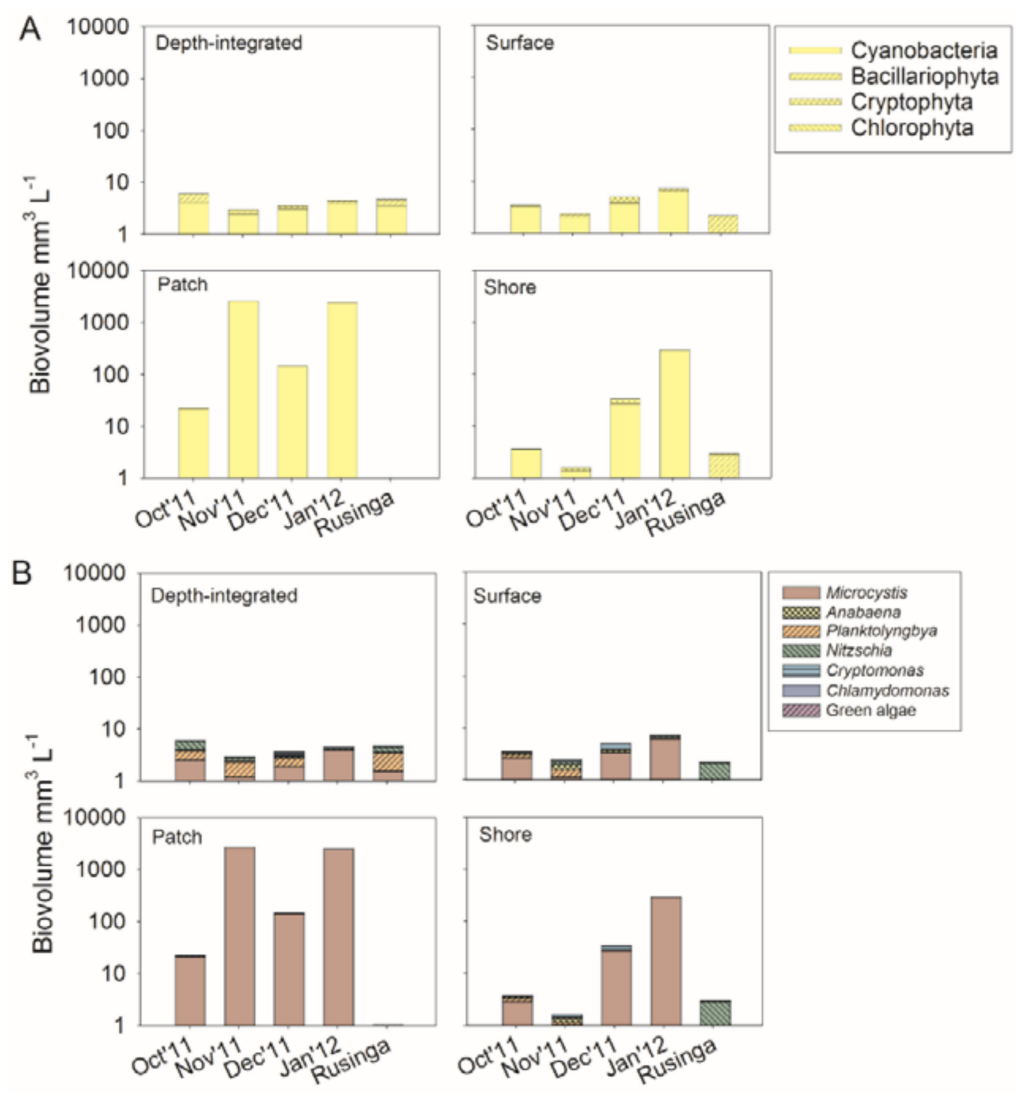

Figure 1. Phytoplankton biovolume composition from different sample types (depth-integrated, surface, patch and shore) in Nyanza Gulf and Rusinga Channel during October 2011 to January 2012. (A) phytoplankton groups (relative proportion $>5 \%$ ), (B) phytoplankton genera (relative proportion $>5 \%$ ). 


\subsection{Microcystin Concentrations in Water}

MC was detected in all water sample types collected from Kisumu Bay $(n=20)$ but not in any samples from Rusinga channel. Four MC structural variants occurred: MC-YR $(m / z=1045$ with retention time of $17 \mathrm{~min}), \mathrm{MC}-\mathrm{LR}(\mathrm{m} / z=995,18 \mathrm{~min})$ and two unknown MC variants eluting at $24 \mathrm{~min}(m / z=1052)$ and $25 \mathrm{~min}(m / z=1002)$, respectively. On average, MC-YR and MC-LR and MC $m / z 1052$ accounted for the major part of the total MC (Table 2). The proportion of MC-YR was significantly higher and that of MC m/z 1052 was lower in patch samples when compared with depth-integrated samples.

Table 2. Average ( $\pm \mathrm{SE}$ ) proportion of microcystin structural variants and microcystin concentrations (in MC-LR equiv.) recorded at Kisumu Bay from various sample types $(n=4)$.

\begin{tabular}{ccccccc}
\hline Structural Variant & Retention (min) & Surface & Integrated & Patch & Shore & $p_{\text {-Value }}{ }^{\mathbf{1}}$ \\
\hline \multicolumn{7}{c}{ Proportion } \\
\hline MC-YR & $17.06-17.26$ & $40 \pm 5^{\mathrm{a}, \mathrm{b}}$ & $26 \pm 6^{\mathrm{b}}$ & $45 \pm 2^{\mathrm{a}}$ & $33 \pm 4^{\mathrm{a}, \mathrm{b}}$ & 0.015 \\
MC-LR & $18.34-18.52$ & $28 \pm 4$ & $18 \pm 4$ & $29 \pm 2$ & $26 \pm 4$ & 0.136 \\
MC $m / z$ 1052 & $23.95-24.16$ & $25 \pm 9$ & $51 \pm 12$ & $16 \pm 1$ & $31 \pm 9$ & 0.05 \\
MC $m / z$ 1002 & $25.0-25.07$ & $7 \pm 3$ & $6 \pm 2$ & $11 \pm 2$ & $9 \pm 2$ & 0.463 \\
\hline \multicolumn{7}{c}{ Concentration $(\mu \mathrm{g} / \mathrm{L})$} \\
\hline MC-YR & $17.06-17.26$ & $0.6 \pm 0.4^{\mathrm{a}, \mathrm{b}}$ & $0.5 \pm 0.1^{\mathrm{b}}$ & $343 \pm 186^{\mathrm{a}}$ & $29 \pm 17^{\mathrm{a}, \mathrm{b}}$ & $<0.001$ \\
MC-LR & $18.34-18.52$ & $1.3 \pm 0.3^{\mathrm{b}}$ & $0.4 \pm 0.1^{\mathrm{b}}$ & $210 \pm 102^{\mathrm{a}}$ & $22 \pm 12^{\mathrm{a}, \mathrm{b}}$ & $<0.001$ \\
MC $m / z 1052$ & $23.95-24.16$ & $1.4 \pm 0.6^{\mathrm{b}}$ & $1.2 \pm 0.3^{\mathrm{b}}$ & $160 \pm 94^{\mathrm{a}}$ & $17 \pm 9^{\mathrm{a}, \mathrm{b}}$ & $<0.001$ \\
MC $m / z$ 1002 & $25.0-25.07$ & $0.6 \pm 0.5^{\mathrm{b}}$ & $0.2 \pm 0.04^{\mathrm{b}}$ & $111 \pm 60^{\mathrm{a}}$ & $9 \pm 5^{\mathrm{a}, \mathrm{b}}$ & $<0.001$ \\
\hline
\end{tabular}

${ }^{1}$ Friedman Repeated Measures ANOVA on Ranks (Superscripts indicate homogeneous subsets not significantly different at $p=0.05$ according to Tukey-test post-hoc pairwise comparison).

The highest total MC concentrations were recorded in patch samples with maximum concentrations exceeding $2 \mathrm{mg} / \mathrm{L}$ of MC-LR equiv. (Figure 2) as recorded in November 2011. MC concentrations also increased in shore water samples exceeding $100 \mu \mathrm{g} / \mathrm{L}$ in January 2012. In contrast, total MC concentrations from depth-integrated and surface samples were below $10 \mu \mathrm{g} / \mathrm{L}$. In general, the dissolved MC showed low concentrations only $(<3.3 \mu \mathrm{g} / \mathrm{L})$. On average, the patch samples had five times higher MC concentration than the depth-integrated sample, while the shore samples had MC concentrations twice that of the depth-integrated sample. For the cell-bound fractions, the MC concentrations were 387, 28 and 2 times higher in the patch, shore and surface water samples respectively when compared with the depth-integrated sample. The total MC concentrations were significantly related to Microcystis cell numbers $\left(n=19, \mathrm{R}^{2}=0.71, p<0.0001\right)$ but not to any other abundant cyanobacteria (i.e., Planktolyngbya, Anabaena) (Supplementary Figure S3). This suggests that other genera than Microcystis potentially producing MC were not important during the study period. Average cellular MC contents varied from 2-250 fg (mean \pm SE, $49 \pm 9$ ) MC per Microcystis cell, and did not differ between sample types (Repeated Measures ANOVA on Ranks, $p=0.139$ ). On a dry weight (DW) basis the average cellular MC content varied from 247 and $261 \mu \mathrm{g} \mathrm{MC} / \mathrm{g}$ DW in depth-integrated and surface samples to $495 \mu \mathrm{g} \mathrm{MC/g}$ DW in patch and shore samples but did not differ between sample types (Repeated Measures ANOVA on Ranks, $p=0.65$ ). Surprisingly, intracellular MC and dissolved $\mathrm{MC}$ concentrations were not related. For example, the highest intracellular MC concentrations in patch samples had only $0.4-3 \mu \mathrm{g} / \mathrm{L}$ of dissolved MC. This discrepancy might be explained by high turbulence induced by wind action leading to a constant dilution of dissolved MC that, however, was overcome by the buoyant Microcystis colonies forming the patches. 

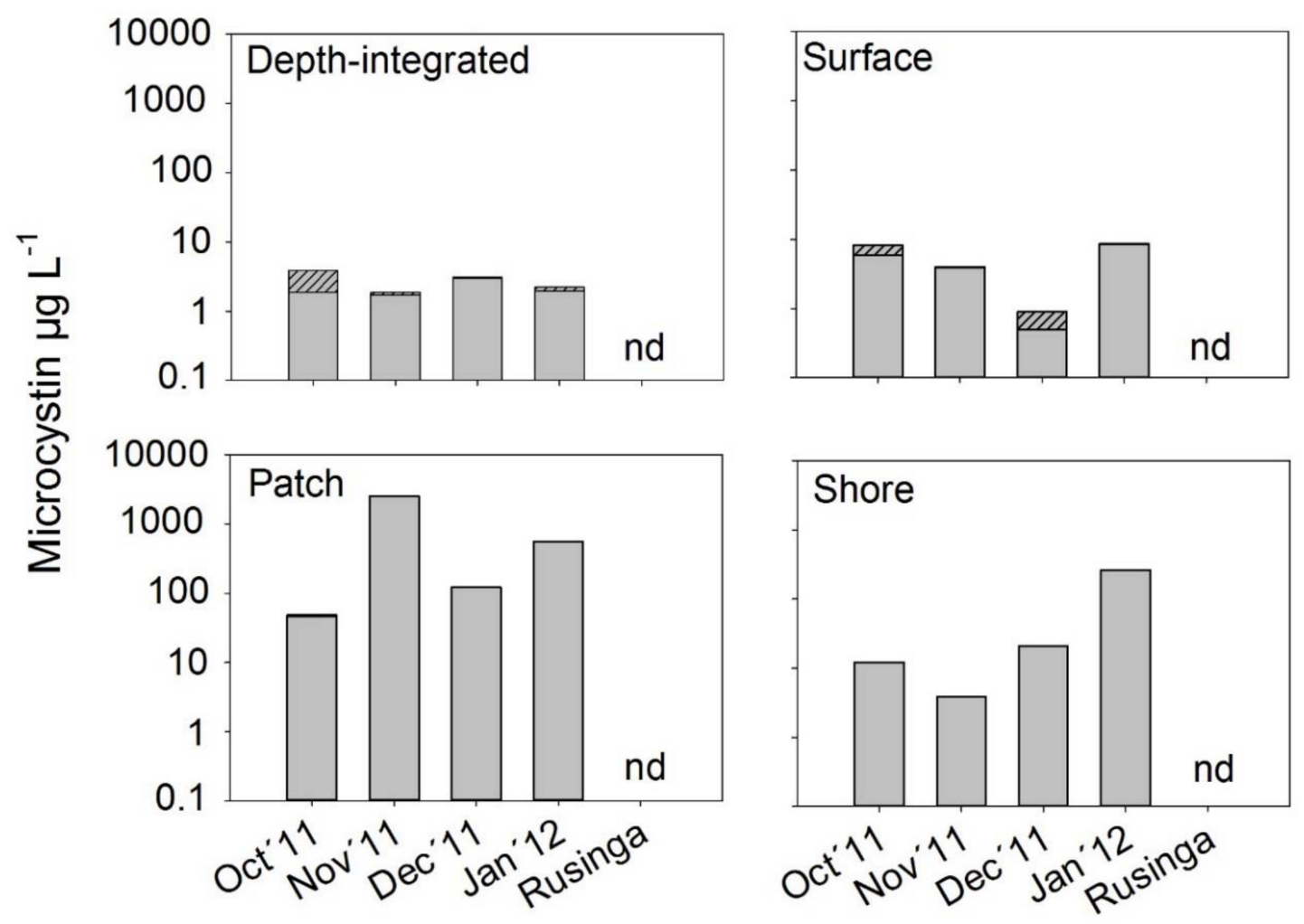

Figure 2. Intracellular microcystin concentrations (in MC-LR equivalents) as determined by HPLC-DAD and dissolved MC concentrations as determined by ELISA from different sample types in Nyanza Gulf and Rusinga Channel during October 2011 to January 2012. (n.d, not detected).

\subsection{Small Fish Species Composition}

The following small fish species were identified in Kisumu Bay (ST1): Barbus sp., Haplochromis sp., Lates niloticus and $R$. argentea. All samples were dominated by $R$. argentea both in terms of individual numbers ( $>55 \%)$ and in terms of fresh weight $(>51 \%)$, (Table 3). In Rusinga channel (ST2) only three fish species were identified (R. argentea, L. niloticus and Barbus sp.) and R. argentea showed the maximum proportion $(95 \%)$.

During the study period, the average fresh weight of individual Barbus sp. was highest (mean $\pm \mathrm{SE}, 1.0 \mathrm{~g} \pm 0.07$ ), while it was $0.6 \mathrm{~g} \pm 0.02$ for $R$. argentea, $0.6 \mathrm{~g} \pm 0.07$ for L. niloticus and $0.6 \mathrm{~g} \pm 0.2$ for Haplochromis sp. In the Rusinga channel, ST2 individuals of L. niloticus were heavier $(1.8 \mathrm{~g} \pm 0.2)$, while $R$. argentea was on average lighter $(0.5 \mathrm{~g} \pm 0.02)$.

In Kisumu Bay, Barbus sp. had the highest total length $(47 \pm 1.3 \mathrm{~mm})$ while $R$. argentea $(39 \pm 0.6 \mathrm{~mm})$, L. niloticus $(35 \pm 1 \mathrm{~mm})$ and Haplochromis sp. $(32 \pm 3 \mathrm{~mm})$ were on average smaller. In Rusinga, L. niloticus was longer $(58 \pm 2 \mathrm{~mm})$, while $R$. argentea $(40 \pm 0.5 \mathrm{~mm})$ did not show a difference in length. As prey size selection depends to a significant extent on fish size, it is concluded from the observed length distribution that the sampled fish were mostly feeding on plankton.

\subsection{Microcystin Content in Small Fish as Determined by Biological and Chemical-Analytical Methods}

MC occurred in fish samples obtained from Kisumu Bay (ST1) and Rusinga channel (ST2), as revealed by both biological methods, ELISA and PPIA. The MC contents ranged from 0-990 
and 11-109 ng MC/g DW for ELISA and PPIA, respectively. Altogether the MC contents as determined in fish by ELISA were linearly related to the MC contents as determined by PPIA: $y=82.2+5.2 \mathrm{x}$, where $\mathrm{y}$ is $\mathrm{MC}$ in $\mathrm{ng} / \mathrm{g}$ DW as determined by ELISA and $\mathrm{x}$ is $\mathrm{MC}$ in $\mathrm{ng} / \mathrm{g} \mathrm{DW}$ as determined by PPIA $\left(\mathrm{R}^{2}=0.29, p<0.0001\right)$. On average, the ELISA-determined MC contents showed a higher variability and exceeded the PPIA-determined MC contents by a factor of $8.2 \pm 0.5$ (Figure 3 ).

All samples obtained from December 2011 were additionally tested for MC content using chemical-analytical methods such as LC-MS/MS $(n=16)$. In four samples, MC-YR was detected ranging from 8-20 ng MC/g DW while the other MC variants were not observed. It is concluded that MC-YR indeed specifically occurred in small fish. However, compared with water samples (i.e., $\mu \mathrm{g}$ of MC per $\mathrm{g}$ DW of plankton biomass as determined by HPLC) the concentration of MC-YR in small fish tissue was found to be very low (i.e., ng of MC per g DW of fish biomass as determined by LC-MS/MS).

Table 3. Number (proportion) of individuals assigned to small fish species sampled in Nyanza Gulf (ST1) during October 2011-January 2012 and in Rusinga channel (ST2) in January 2012, as well as average \pm SE (min-max) fresh weight and total length.

\begin{tabular}{ccccc}
\hline & Barbus sp. & Haplochromis sp. & L. niloticus & R. argentea \\
\hline Number (Proportion) \\
\hline ST1, October 2011 & $26(33)$ & $2(2.6)$ & $6(7.8)$ & $43(55.5)$ \\
ST1, November 2011 & $17(10)$ & $2(2.2)$ & $51(30.5)$ & $97(58)$ \\
ST1, December 2011 & $3(2.5)$ & 0 & $44(37.3)$ & $71(60.2)$ \\
ST1, January 2012 & $19(13)$ & 0 & $18(12.6)$ & $106(74.1)$ \\
ST2, January 2012 & $1(0.1)$ & 0 & $6(4.2)$ & $137(95.1)$ \\
\hline & Fresh weight (g) & $0.5 \pm 0.1(0.3-1.7)$ \\
ST1, October 2011 & $1.2 \pm 0.1(0.1-2.6)$ & $(0.3-0.4)$ & $0.7 \pm 0.3(0.2-1.9)$ & $0.6 \pm 0.1(0.1-1.6)$ \\
ST1, November 2011 & $1 \pm 0.1(0.4-2.4)$ & $(0.5-1.2)$ & $0.8 \pm 0.1(0.2-4.2)$ & $0.6 \pm 0(0.1-1.2)$ \\
ST1, December 2011 & $1.4 \pm 0.3(1.1-2)$ & - & $0.6 \pm 0.1(0.1-4.6)$ & $0.5 \pm 0(0.1-1.3)$ \\
ST1, January 2012 & $0.7 \pm 0.1(0.3-1.9)$ & - & $0.3 \pm 0.0(0.1-0.7)$ & $0.5 \pm 0(0.1-1.5)$ \\
ST2, January 2012 & 1.2 & - & $1.8 \pm 0.2(1.3-2.3)$ & \\
\hline & & & $35 \pm 5(21-53)$ & $44 \pm 1(30-56)$ \\
ST1, October 2011 & $47 \pm 3(19-64)$ & Total length (mm) & $36 \pm 2(10-58)$ \\
ST1, November 2011 & $48 \pm 2(38-65)$ & $(31-40)$ & $34 \pm 2(17-70)$ & $44 \pm 1(20-56)$ \\
ST1, December 2011 & $56 \pm 4(51-63)$ & - & $30 \pm 3(17-62)$ & $36 \pm 1(4-60)$ \\
ST1, January 2012 & $40 \pm 2(29-60)$ & - & $58 \pm 2(50-61)$ & $40 \pm 1(27-56)$ \\
ST2, January 2012 & 56 & - &
\end{tabular}

\subsection{Microcystin Content in Small Fish in Relation to MC in Phytoplankton}

Over the study period, fish samples originating from Kisumu Bay (ST1) had a higher MC content when compared with fish samples obtained from Rusinga channel (ST2), i.e., MC contents ranged from $190 \pm 51$ to $543 \pm 26 \mathrm{ng} \mathrm{MC} / \mathrm{g}$ DW in Kisumu Bay vs. $56 \pm 56 \mathrm{ng} \mathrm{MC} / \mathrm{g}$ DW in Rusinga channel as determined by ELISA (Repeated Measures ANOVA on Ranks, $p=0.034$, Tukey test $p$ < 0.05). Analogously, MC content varied from $43 \pm 10$ to $95 \pm 14 \mathrm{ng} \mathrm{MC/g} \mathrm{DW}$ in Kisumu Bay vs. $14 \pm 0.8 \mathrm{ng} \mathrm{MC/g}$ DW in Rusinga channel as determined by PPIA (Repeated Measures ANOVA on Ranks, $p=0.107)$, (Figure 4). Thus the MC content in fish was related to the MC content in the seston, i.e., higher MC contents in fish from Kisumu Bay vs. lower MC contents in fish sampled from more open water at Rusinga channel. Using both biological methods the MC content in fish was found decreased by a factor of $10^{3}$ implying significant biodilution rather than biomagnification through the food chain. 


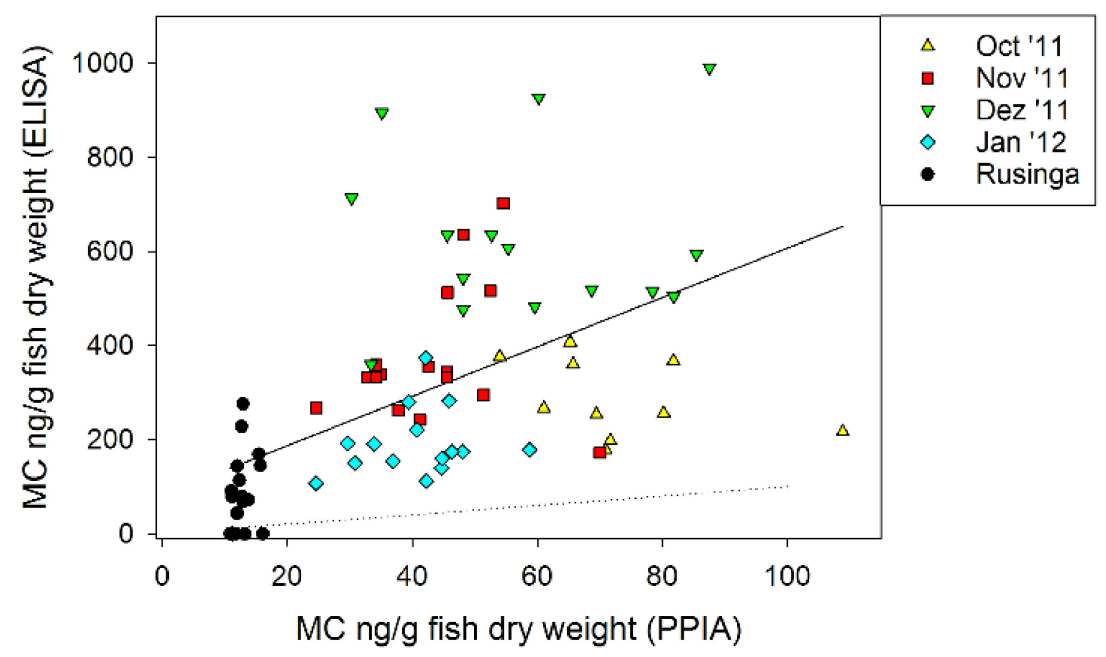

Figure 3. Correlation of microcystin contents in small fish ( $\mathrm{ng} / \mathrm{g}$ in dry weight) as determined by ELISA vs. microcystin contents as determined by the PPIA $\left(R^{2}=0.29, p<0.0001\right)$. The PPIA results were on average 8.2 ( \pm 0.5 )-fold lower than those obtained by ELISA. The one-to-one relationship is indicated by the dotted line.

In order to find out whether the air-drying time influenced the MC content in small fish, the proportion of MC content in relation to $t_{0}$ was calculated. There was no clear trend in MC content in relation to MC content at $t_{0}$ for all sampling dates as inferred from the ELISA. However, there was a decrease in MC content as determined from PPIA in relation to $t_{0}$ with an increase in exposure time (2-8 h) in October and December samples (Figure 5). During the December experiment, the average MC content $77 \pm 5 \mathrm{ng} \mathrm{MC} / \mathrm{g}$ DW significantly decreased down to $36 \pm 5 \mathrm{ng} \mathrm{MC} / \mathrm{g}$ DW (Repeated Measures ANOVA on Ranks, $p<0.027)$. During October, the average MC content $95 \pm 14 \mathrm{ng} \mathrm{MC} / \mathrm{g}$ DW also decreased down to $69 \pm 6 \mathrm{ng}$ MC/g DW (Repeated Measures ANOVA on Ranks, $p=0.147$ ). The recording of meteorological data at Kisumu Airport showed relatively low variability in daily temperature $\left(22.7-25^{\circ} \mathrm{C}\right)$ and irradiance $\left(866-1387 \mu \mathrm{mol}\right.$ photons. $\mathrm{m}^{-2} \cdot \mathrm{s}^{-1}$, Supplementary Table S2). In contrast, the relative humidity varied and showed maxima of $80 \%$ in October and December while it was lower in November (35\%) and in January 2012 (62-66\%), (Supplementary Table S2). In summary, the $\mathrm{MC}$ content in small fish showed a relatively high stability during the drying process and the overall relation to $\mathrm{MC}$ content in seston was not changed.

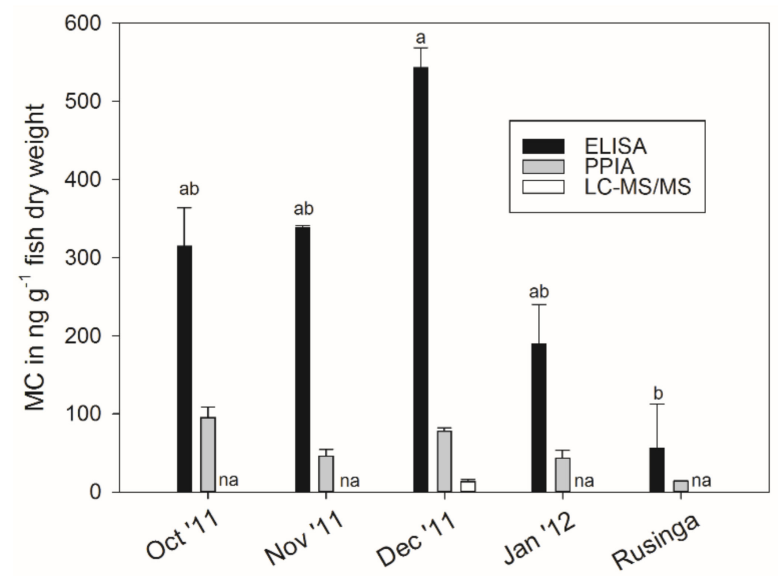

Figure 4. Mean $( \pm \mathrm{SE})$ microcystin contents in small fish (in $\mathrm{ng} / \mathrm{g}$ dry weight) as determined by ELISA and PPIA and LC-MS/MS originating from Kisumu Bay in Nyanza Gulf and Rusinga Channel during October 2011 to January 2012 (n.a, not analyzed). Letters indicate subgroups not significantly different at $p<0.05$ if an overall difference was found (Friedman Repeated Measures ANOVA on Ranks). 


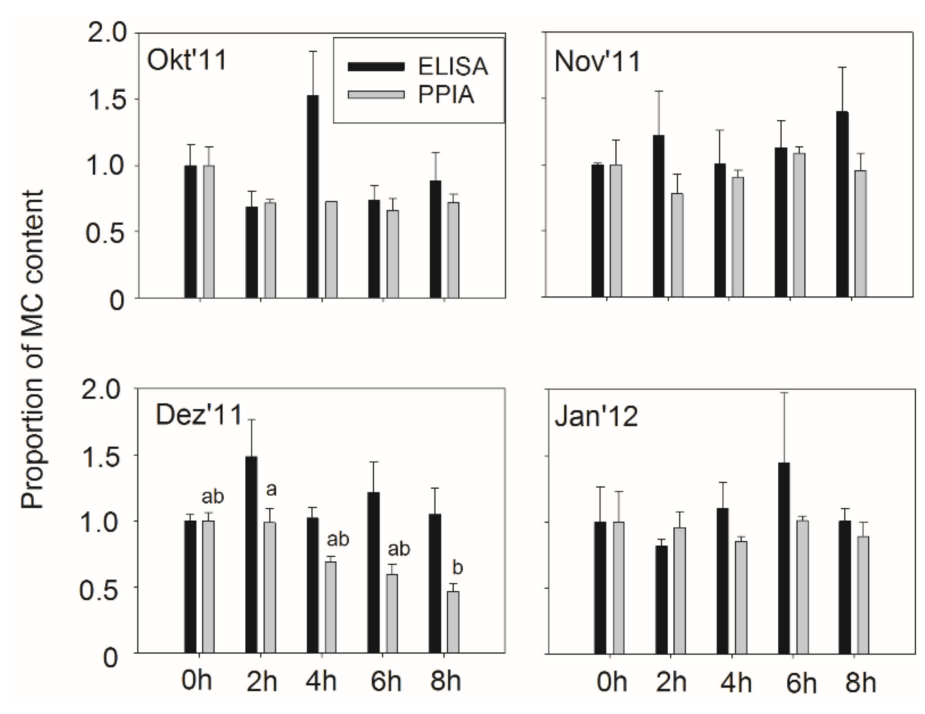

Figure 5. Mean ( $\pm \mathrm{SE}$ ) proportion of microcystin contents in small fish after $0-8 \mathrm{~h}$ of sun drying. Letters indicate subgroups not significantly different at $p<0.05$ if an overall difference was found (Friedman Repeated Measures ANOVA on Ranks).

\section{Discussion}

\subsection{Eutrophication and Spatial Variability of Phytoplankton Composition}

The Nyanza Gulf is a semi-closed bay, therefore, it has a limited exchange of water with the main basin which is related to increased turbidity due to high algal biomass [28,29]. In other bays of Lake Victoria and open waters such as the Rusinga channel, there is dilution because of water exchange with the main basin, which can explain the lower phytoplankton biovolume [4]. Besides algal growth, the suspended solids from three river inflows in this area (Sondu, Kisat and Nyamasaria) also further increase the turbidity, i.e., satellite images show sediment-laden inflow waters during the rainy seasons [29]. The high turbidity reduces light availability and selectively favors specialized algal species such as Microcystis capable of remaining near the water surface through the presence of gas vesicles [30]. Particularly in shallow aquatic ecosystems, buoyant cyanobacteria of the genus Microcystis are favored by both eutrophication and turbidity and have been found to be dominant in freshwater ecosystems which are naturally eutrophic (such as Lake George in Uganda) [14]. The larger size of the buoyant colonies not only enables pronounced vertical migration but also accumulation within Langmuir circulation where positively buoyant particles will accumulate above the downwelling region [31]. In contrast, nonbuoyant phytoplankton such as cyanobacteria Planktolyngbya and diatoms of the genus Nitzschia were unaffected when compared with depth-integrated samples and thus reduced in proportion. For another large lake, Lake Biwa in Japan, Ishikawa et al. [31] further described large circular horizontal currents that accumulate Microcystis in the center transporting Microcystis from inshore to offshore areas. Indeed, for the eastern part of the Nyanza Gulf a large circular current has been described which contributes to the strong horizontal gradient in salinity from the eastern part to the western part towards the main basin [29]. The larger scale hydrodynamic forces may help in supporting the more stable formation of Langmuir circulations which depend on moderate wind speed and the presence of wind waves [31]. In general, the pronounced physico-chemical gradient from the eastern part to the western part of Nyanza Gulf has been increased by reducing the hydrological connectivity to the main basin [31]. Most importantly, a causeway was constructed to link Rusinga island with the main land in 1983, which reduced the water exchange with the main basin [32]. However, in May 2017, the Mbita channel was re-opened to reconnect Nyanza Gulf with the main Lake Victoria besides Rusinga channel. This opening (now called Mbita channel) with a width 
of $150 \mathrm{~m}$ is supposed to increase ecological and hydrological connectivity and might also reduce the internal physical stability of the eastern part of Nyanza Gulf.

\subsection{Spatial Variability of Microcystin Concentration in Water}

Spatial and temporal variability in MC concentration has been described along the shoreline of wind-exposed systems worldwide and has been considered as an important variable in estimating health risks through exposure to toxic algal blooms. While maximum MC concentrations are typically observed along the shore [10], in this study, maximum MC concentrations occurred within the patches drifting at the surface in Kisumu Bay (Supplementary Figure S1). The positive correlation between MC concentration and Microcystis cell numbers showed that Microcystis sp. was the major MC producer while the contribution of other cyanobacteria species was of minor importance. This is in agreement with earlier results from Uganda and Nyanza Gulf, respectively $[9,15]$. Thus the lack of detectable MC in all sample types obtained from Rusinga channel can be best explained by the general lowest numbers of Microcystis ( $<100$ cells $/ \mathrm{mL}$ ). In contrast, in the eutrophic Nyanza Gulf, the selective entrainment of Microcystis in the Langmuir circuits as described above increased the horizontal patchiness in MC concentration considerably. When compared with depth-integrated samples, the proportions of the more abundant MC structural variants changed, i.e., the proportion of MC-YR increased and the unknown MC m/z 1052 variant decreased (Table 2). This change in MC-variant proportion might imply a change in genotype composition of Microcystis sp., for example, through favoring the large sized colonies such as M. aeruginosa vs. other morphospecies that occur as smaller sized colonies [33]. The genus Microcystis shows impressive variability of cell numbers per colony ranging from a few cells to $>10^{5}$ cells, which can be explained in part by the variable cationic chemical composition of the mucilage embedding the cells [34]. Notably, the large sized Microcystis colonies frequently show maximum MC contents while smaller sized Microcystis colonies typically show the lowest MC contents, i.e., as reported from Wannsee in northern Germany [33], from northern Missouri and Iowa in North America [35] and Lake Taihu in China [36]. Thus, the rather high MC concentrations observed in this study within the patches may be further increased by selective enrichment of large sized buoyant Microcystis colonies.

\subsection{Microcystin Content in Small Fish as Determined by Biological and Chemical-Analytical Methods}

The extraction and detection of MC from complex matrices such as fish tissue is an important question and both free and covalently-bound MC need to be distinguished [37]. Methods measuring free MC may underestimate the total MC content because of covalent binding of the Methyl-dehydro-alanine (Mdha) residue in pos. 7 of the MC molecule to the active site of PP or other cysteine-containing peptides such as glutathione. These covalently bound MC can be released by oxidation through the so-called Lemieux technique resulting in an oxidative derivative of the Adda side chain as 2-methyl-3-methoxy-4-phenylbutyric acid (MMPB) which is measured by LC-MS/MS [38]. It is under question whether the covalently bound MC is toxicologically active, i.e., through slow release by digestive enzymes during gut passage [39]. The proportion of covalently-bound $\mathrm{MC}$ in fish tissue can be substantial [20] (and references therein) and ELISA has been shown to be able to detect the cysteine-MC and the glutathione conjugates. Thus, it is not surprising that MC concentrations as estimated by ELISA were highest also in this study because of its crossreactivity with both detoxification and PP conjugates.

In contrast to ELISA, the PPIA measures the effect of inhibitors such as MC on the activity of PP monitored through enzymatic release of a chromogenic substrate. Thus the PPIA quantifies the toxicity of a sample and yields toxicity equivalents. ELISA is based on structural recognition of MC molecules and is designed to yield toxin concentrations in MC-LR equivalents. As other natural products of cyanobacteria (e.g., anabaenopeptins, okadaic acid) also inhibit PP and MC structural variants differ in activity, the results obtained by the two biological methods cannot be directly compared. However, in general, PPIA is expected to target the free MC.

On the other hand, chemical-analytical techniques such as LC-MS/MS are known to be highly specific with high resolution and are able to detect known MC molecule parent and fragment ions 
even in complex sample matrices [8]. However, because of the high target molecule specificity, covalently-bound MC also is likely overlooked. This target molecule specificity is less relevant in LC-DAD (UV based) methods, however, the latter are generally less sensitive and suffering from sample matrix effects [8]. In summary, it is rather the combination of biological and chemical-analytical methods that is used to evaluate the exposure risk through small fish consumption. In this study the occurrence of MC-YR in fish sample extracts was unambiguously identified while the MC contents estimated by ELISA might imply a significant share of bound MC through various catabolic processes. Since the actual toxicity is most directly addressed by the PPIA, in this study the PPIA-derived estimates have been used to estimate the exposure risk.

\subsection{Microcystin Content in Small Fish}

The MC contents, as determined by ELISA in this study (190 \pm 51 to $543 \pm 26 \mathrm{ng}$ MC/g DW), were in the range of MC contents reported previously by Poste et al. [23,40]. For example, R. argentea and Haplochromis sp. species sampled from Murchison Bay and Napoleon Gulf contained 36-41 and $39-129 \mu \mathrm{g} / \mathrm{kg}$ wet weight that would translate into 360-1290 $\mu \mathrm{g} / \mathrm{kg}$ DW (assuming dry weight to be $10 \%$ of wet weight). The MC contents derived by ELISA were quantitatively supported by PPIA, i.e., small fish sampled from Rusinga channel contained significantly less MC as observed by both methods (Figures 3 and 4). The general experience is that active MC have a proportion which is one order of magnitude lower when compared with the total extractable MC [20]. Indeed, in this study MC contents in small fish, as estimated by PPIA, were on average eight-fold lower when compared with ELISA-derived estimates. The World Health Organization (WHO) recommended the tolerable daily intake (TDI) for MC over the lifetime of a human being to be $0.04 \mu \mathrm{g}$ MC-LR equivalents per $\mathrm{kg}$ of body weight per day [24]. Using this guideline, the tolerable dose of MC-LR is calculated assuming a consumption of $100 \mathrm{~g}$ (wet weight) of fish per day. In this study, the PPIA-derived estimate would translate to 246-519 \pm 24-1089 ng of MC-LR equiv. (min-mean \pm SE-max) consumed from small fish in Kisumu bay per day, which would be below the theoretical tolerable intake for an adult $(2.4 \mu \mathrm{g}$ for a $60 \mathrm{~kg}$ adult).

When compared with muscle tissue, the higher MC contents can be explained by the inclusion of the viscera containing Microcystis colonies in the analyzed sample [20]. As small fish have been found to contain a significant amount of Microcystis in their diet (e.g., $80 \%$ of phytoplankton), this diet-based vector is considered a relevant one [21]. The surprisingly high proportion of phytoplankton (Microcystis sp.) in the diet of zooplanktivorous fish may be linked to the general high turbidity in the Gulf system but also has been reported from other systems (e.g., in Rwanda [41]). Currently, the diet composition and the possible relation to MC content in small fish along the eutrophication gradient in Nyanza Gulf is not known but should be explored further. The feeding behavior of small fish and a possible avoidance of the observed patches with Microcystis dominance and maximum MC concentrations would also be a research route. On the other hand, the lysed cyanobacteria in the gut actually release not only the MC but also photopigments such as phycobilins known to act as photo sensitizers accelerating the photolysis of MC [42]. Thus, exposure of the small fish containing phytoplankton in the diet in the sunlight actually might result in reduced MC contents. In this study, such significant reduction in MC content was only observed at relatively high humidity conditions (Figure 5, Supplementary Table S2). This result would imply that an accelerated drying process actually would reduce the photolysis potential because photocatalyzed degradation is occurring in the aquatic solution [43]. Nevertheless, the photolysis-induced MC degradation would be a relatively simple measure to reduce the MC content in the small fish, for example, by maintaining the humidity of the fish biomass during a certain time of sun exposure.

\section{Conclusions}

The eutrophication of the eastern part of Nyanza Gulf has led to high concentrations of MCs, which is mainly caused by the dominance of the bloom-forming cyanobacterium of the 
genus Microcystis. The buoyant Microcystis colonies accumulated in the patches through advective currents possibly formed by Langmuir circulations linked to maximum MC concentrations in the patches. In consequence, MC contents have been observed in small planktivorous fish species such as $R$. argentea. Although active MC in small fish was detected regularly, the theoretical lifetime tolerable daily intake for adults was not exceeded. The fish drying process in the sun did not consistently reduce the MC content in the fish which might be explained by the variable relative humidity. However, since photocatalyzed degradation of MC in the sunlight is a fast process, exposing the fish in wet conditions to the sun for a short time period might be a possibility to reduce MC content in food.

\section{Materials and Methods}

\subsection{Study Area and Sampling}

Nyanza Gulf is located in the North-Eastern part of L. Victoria and is connected to the main basin via the Rusinga channel. Besides Mwanza Gulf (Tanzania) and Napoleon Gulf (Uganda), Nyanza Gulf is one of the largest bays of Lake Victoria with an area of $1400 \mathrm{~km}^{2}$. With an average depth of $5 \mathrm{~m}$, it is relatively shallow in comparison with the main basin [28]. Samples were collected monthly (from October 2011 to January 2012) at one sampling station in eutrophic Kisumu Bay (ST1: S $00^{\circ} 10^{\prime} 26.7^{\prime \prime}$ E $34^{\circ} 44^{\prime} 11.7^{\prime \prime}$ ) and once in January 2012 in Rusinga Channel (ST2: S $00^{\circ} 22^{\prime} 46.2^{\prime \prime}$ E $34^{\circ} 11^{\prime} 15.0^{\prime \prime}$ ), (Figure 6). Water temperature, dissolved oxygen, $\mathrm{pH}$ and conductivity were determined at 1-m depth using a multiprobe (Hach-Lange, Düsseldorf, Germany).

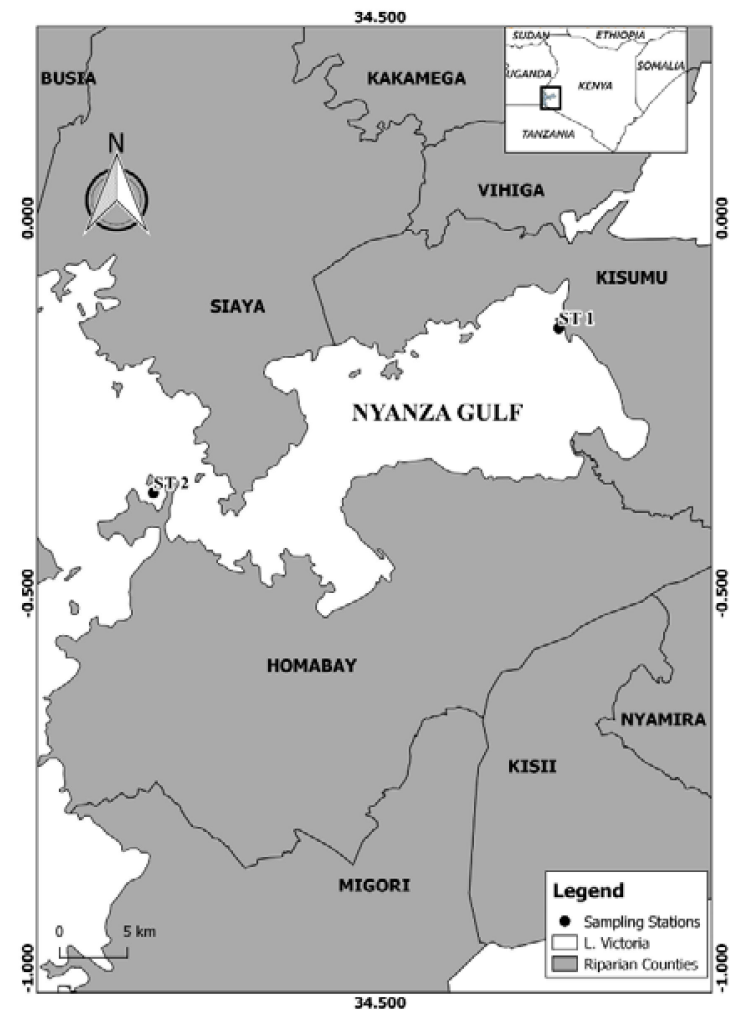

Figure 6. Map of Lake Victoria, Kenyan side, showing Nyanza Gulf and the two sampling stations (ST1, Kisumu Bay and ST2, Rusinga Channel).

Depth-integrated water samples were obtained by mixing 1 liter collected from every meter through the water column down to $3 \mathrm{~m}$ depth using a Van Dorn sampler. Surface samples were taken from scums visible as patches possibly formed by Langmuir spirals ("patch" samples) or at the 
shore ("shore" samples). Water samples were filtered using Whatman GF/C filters. For chlorophyll $a$ analysis, the filters were stored frozen and processed the following day. For cell bound MC analysis, filters were dried overnight $\left(50^{\circ} \mathrm{C}\right)$ and stored frozen. The filtrate was used for determination of dissolved MC in water using ELISA.

\subsection{Phytoplankton Composition and Abundance}

Chlorophyll $a$ was extracted using hot ethanol [44]. Phytoplankton composition was determined from $2 \mathrm{~mL}$ of Lugol-fixed samples using an inverted microscope at $400 \times$ magnification [45]. Phytoplankton taxa were identified from morphological characteristics according to Talling, Komàrek and Kling, Cronberg and Anadotter [46-48]. In general, phytoplankton specimen were counted as distinct cells (Microcystis sp., Anabaena (Dolichospermum) sp., Merismopedia sp.; or the pennate diatom Nitzschia sp.). Filamentous cyanobacteria were counted as filaments (Planktolyngbya sp.). In order to determine phytoplankton biovolume of individual taxa the biovolume was determined by geometric approximation [45]. To quantify Microcystis cells the colonies were disintegrated into single cells using sonication for $10 \mathrm{~s}$ (output 40 watt) by a sonicator (Heat Systems-Ultrasonics, Inc., Plainview, NY, USA, 11,803) [49]. Pilot experiments revealed that maximum Microcystis cell numbers were obtained after 10 sonication treatments (in $10 \mathrm{~mL}$ volume).

\subsection{Microcystin Determination in Water}

The dissolved MC in water was determined directly in the filtrate using indirect competitive ELISA (Abraxis LLC, Warminster, PA, USA, Microcystins-ADDA ELISA kit, PN 520011) according to the manufacturer's instructions and reading absorbance was calibrated though the provided MC-LR standards at $450 \mathrm{~nm}$ wavelength. The ELISA has a limit of detection of $0.1 \mathrm{ng} / \mathrm{mL}(0.1 \mu \mathrm{g} / \mathrm{L})$. For the cell-bound fraction of MC, cells were collected on filters and biomass was extracted in aqueous methanol $(75 \%, w / v)$ according to Fastner et al. [50]. MC structural variants were chromatographically separated using High performance liquid chromatography with diode array detection (HPLC-DAD) as described [33]. MC variants were identified by their characteristic absorption spectra and retention times [15] and quantified at $240 \mathrm{~nm}$ wavelength. Using MC-LR as the external standard, the concentration of MC-LR equivalents was calculated from the regression curve $y=1885.3 x-6.8775$, $\left(\mathrm{R}^{2}=0.99\right)$, where (y) was the absorption (mAU) recorded at $240 \mathrm{~nm}$ and $\mathrm{x}$ represented the injected concentration (ng) of MC-LR standard (CyanoBiotech GmbH, Berlin, Germany). Under the specified conditions, $50 \mathrm{ng}$ of MC-LR equivalents injected could be resolved resulting in a theoretical limit of detection of $300 \mathrm{ng}$ of MC-LR ( $=0.6 \mu \mathrm{g} / \mathrm{L}$ assuming a typical filtration volume of $500 \mathrm{~mL}$ ).

\subsection{Fish Sampling}

Fishing for small fish (mostly $R$. argentea) was performed using light attraction by means of kerosene pressure lamps floating on the water surface during moonless nights. Samples were obtained monthly from fishermen early in the morning from Kisumu Bay (ST1) during October 2011-January 2012 as well as Rusinga channel (ST2) in January 2012. Fish samples were packed immediately on ice and were transported to the laboratory for further processing within $12 \mathrm{~h}$. Fish samples were subsampled, taking aliquots of approximately $80 \mathrm{~g}$ wet weight at random. The species composition, fresh weight $(\mathrm{g})$ and total length $(\mathrm{mm})$ for each specimen from one aliquot subsample were determined. Fish samples were dried either directly $\left(50^{\circ} \mathrm{C}\right)$ or dried under the sun for 2, 4, 6 and 8 hours respectively, and subsequently dried at $50^{\circ} \mathrm{C}$ (Figure 7, Supplementary Figure S4). Individual fish sample aliquots had a dry weight of $18.3 \pm 0.6$ (mean $\pm \mathrm{SE}$ ), $16.8 \pm 0.2,16.6 \pm 0.3$, $16.9 \pm 0.2,17.1 \pm 0.2 \mathrm{~g}$ in October, November, December, and January at ST1 and in January at $\mathrm{ST} 2$, respectively. 


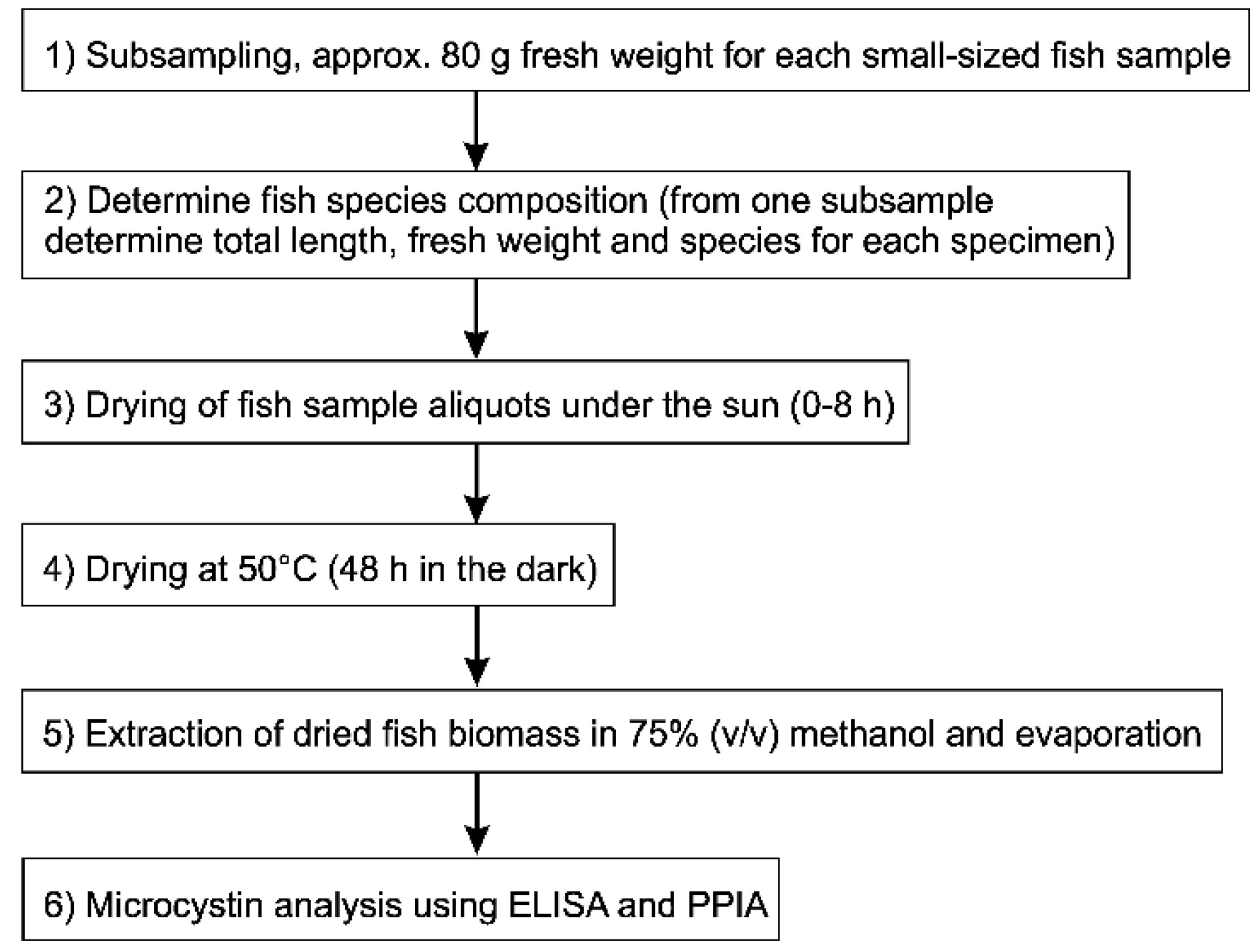

Figure 7. The workflow for fish sample processing including sampling, drying, extraction and $\mathrm{MC}$ analysis.

\subsection{Microcystin Analysis in Small Fish}

MC extraction from dried fish samples was done by aqueous methanol as described [51]. The extraction process was repeated three times. In the first two extraction steps, the dried and weighed fishes were ground as a whole in a mortar and extracted in $75 \%(v / v)$ methanol $(2 \mathrm{~h}$, $\left.4{ }^{\circ} \mathrm{C}\right)$. After centrifugation the pellet was resuspended in $30 \mathrm{~mL}$ of $75 \%(v / v)$ methanol containing $0.002 \%(v / v)$ glacial acetic acid $\left(24 \mathrm{~h}, 4{ }^{\circ} \mathrm{C}\right)$. The next day the pooled supernatant was centrifuged to remove particles and the cleared extract was evaporated to dryness (BUCHI Rota vapor R-205) and stored at $-20^{\circ} \mathrm{C}$. The residues from the evaporation were resuspended in $2 \mathrm{~mL}$ of methanol and transferred to glass bottles kept open under the fumehood overnight to evaporate the methanol (as methanol is known to interfere with ELISA, [52]). To enhance the evaporation of methanol the extract was incubated at $60^{\circ} \mathrm{C}$ for another $2 \mathrm{~h}$. The extract was then diluted with distilled water (1:1000) in glass vials and MCYST concentration was determined by the same indirect competitive ELISA (Microcystins-ADDA ELISA kit, PN 520011) as described above. Using the same MC-LR standard, the concentrations were expressed as MC-LR equivalents in nanograms per gram of fish dry weight. In order to identify the proportion of active MC in the fish tissues the standard protein phosphatase inhibition assay (PPIA) technique [53] was used for aliquots of the fish extract samples dissolved in methanol and stored at $-20^{\circ} \mathrm{C}$. A commercially available microplate test kit (Microcystest) from Zeulab (Zaragoza, Spain) has been used and 250-fold dilutions of fish sample extracts were analyzed according to the manufacturer's instructions. The inhibition of the PP2A activity was monitored using the conversion of chromogenic substrate and reading absorbance at $405 \mathrm{~nm}$ wavelength. Finally, using all fish samples from December 2011 the MC was quantified using chemical-analytical methods by LC-MS/MS [19]. The tandem mass-spectrometry instrumental setup included a water ACQUITY UPLC system directly connected to a Quattro Premier XE MS/MS detector. MC structural variants were quantified in positive ESI mode using multiple reaction monitoring according to the retention time and the precursor ion. The daughter ion monitored for all MCs was the typical 135 Da Adda fragment. All MS settings were optimized with commercial standards (purchased from 
Sigma, Oslo, Norway) which were also used to calibrate the system: MC-RR $m / z=519.8[\mathrm{M}+2 \mathrm{H}]^{2+}$, MC-YR $m / z=1045.5[\mathrm{M}+\mathrm{H}], \mathrm{MC}-\mathrm{LR} m / z=995.5[\mathrm{M}+\mathrm{H}]$. The detection limit was $40 \mathrm{ng} / \mathrm{mL}$ for MC-YR and MC-LR (10 $\mu \mathrm{L}$ injection volume).

\subsection{Statistical Analysis}

Phytoplankton composition and MC contents were compared between samples using the Friedman repeated measures analysis of variance (ANOVA) on ranks $(p<0.05)$ followed by pairwise multiple comparison (Tukey test, $p<0.05$ ) using SigmaPlot (Version 13.0, Systat Software Inc, San Jose, CA, USA).

Supplementary Materials: The following are available online at http:/ /www.mdpi.com/2072-6651/10/7/275/s1, Figure S1: Sampling sites in Nyanza Gulf, L. Victoria showing cyanobacteria mass accumulation, Figure S2: Relationship between total phytoplankton biovolume $\left(\mathrm{mm}^{3} \mathrm{~L}^{-1}\right)$ and Chlorophyll $a\left(\mu \mathrm{g} \mathrm{L}^{-1}\right)$ for all water samples from different sample types in Kisumu Bay, Nyanza Gulf, and Rusinga Channel, Lake Victoria, Figure S3: Relationship between Microcystis cell numbers and total (intracellular and dissolved) MC concentration for all water samples from different sample types in Kisumu Bay, Nyanza Gulf, and Rusinga channel, Lake Victoria, Figure S4: Drying of fish samples for the experiment on microcystin stability $(0-8 \mathrm{~h})$ and for the market, Table S1: Phytoplankton taxa which were discriminated for biovolume estimation, Table S2: Meteorological characteristics for dates of fish drying to study the stability of microcystin in fish samples.

Author Contributions: R.K. and B.M.S. conceived and designed the experiments; B.M.S. performed the experiments; R.K. and B.M.S. analyzed the data; S.O.O., L.S. and T.R. contributed reagents/materials/analysis tools; B.M.S. and R.K. wrote the paper.

Funding: This research was funded by [Austrian Science Fund (FWF)] grant number [P24070] to R.K., and [OEAD GmbH] Appear Ph.D. fellowship (2017-2020) to B.M.S., and [International Postgraduate Course of Limnology] MSc fellowship to B.M.S.

Acknowledgments: We are grateful to Gerold Winkler and Regina Brandstaetter for their support and funding of the practical work through the International Postgraduate Training Course in Limnology (IPGL). We thank James Outa and Brenda Apiyo for assistance during field sampling. Jared Ochieng and Harman Otieno (University of Egerton, Department of Chemistry) assisted in sample processing and analysis. The Meteorological Station at the Kisumu International Airport kindly provided weather data during the fish drying experiments. The authors are grateful for the critical suggestions of two anonymous reviewers which helped to improve this manuscript.

Conflicts of Interest: The authors declare no conflict of interest. The founding sponsors had no role in the design of the study; in the collection, analyses, or interpretation of data; in the writing of the manuscript, and in the decision to publish the results.

\section{References}

1. Verschuren, D.; Johnson, T.C.; Kling, H.J.; Edgington, D.N.; Leavitt, P.R.; Brown, E.T.; Talbot, M.R.; Hecky, R.E. History and timing of human impact on Lake Victoria, East Africa. Proc. R. Soc. B 2001, 269, $289-294$. [CrossRef] [PubMed]

2. Hecky, R.E.; Muggide, R.; Ramlal, P.S.; Talbot, M.R.; Kling, G.W. Multiple stressors cause rapid ecosystem change in Lake Victoria. Freshw. Biol. 2010, 55, 19-42. [CrossRef]

3. Tamatamah, R.A.; Hecky, R.E.; Duthie, H. The atmospheric deposition of phosphorus in Lake Victoria (East Africa). Biogeochemistry 2005, 73, 325-344. [CrossRef]

4. Mbonde, A.S.; Sitoki, L.; Kurmayer, R. Phytoplankton composition and microcystin concentrations in open and closed bays of Lake Victoria, Tanzania. Aquat. Ecosyst. Health Manag. 2015, 18, 212-220. [CrossRef] [PubMed]

5. Gikuma-Njuru, P.; Hecky, R.E.; Guildford, S.J.; MacIntyre, S. Spatial variability of nutrient concentrations, fluxes, and ecosystem metabolism in Nyanza Gulf and Rusinga Channel, Lake Victoria (East Africa). Limnol. Oceanogr. 2013, 58, 774-789. [CrossRef]

6. Calamari, D.; Akech, M.O.; Ochumba, P.B.O. Pollution of Winam Gulf, Lake Victoria, Kenya: A case study for preliminary risk assessment. Lakes Reserv. Res. Manag. 1995, 1, 89-106. [CrossRef]

7. Kling, H.J.; Mugidde, R.; Hecky, R.E. Recent changes in the phytoplankton community of Lake Victoria in response to eutrophication. In The Great Lakes of the World (GLOW): Food Web, Health 
and Integrity; Munawar, M., Hecky, R.E., Eds.; Ecovision World Monograph Series; Backhuys Publishers: Leiden, The Netherlands, 2001; pp. 47-65. ISBN 978-0-9921007-8-0.

8. Meriluoto, J.; Spoof, L.; Codd, G.A. Handbook of Cyanobacterial Monitoring and Cyanotoxin Analysis; John Wiley \& Sons, Ltd.: Chichester, UK, 2017; p. 576. ISBN 9781119068747.

9. Sitoki, L.; Kurmayer, R.; Rott, E. Spatial variation of phytoplankton composition, biovolume, and resulting microcystin concentrations in the Nyanza Gulf (Lake Victoria, Kenya). Hydrobiologia 2012, 691, 109-122. [CrossRef] [PubMed]

10. Humbert, J.-F.; Fastner, J. Ecology of cyanobacteria. In Handbook of Cyanobacterial Monitoring and Cyanotoxin Analysis; Meriluoto, J., Spoof, L., Codd, G.A., Eds.; John Wiley \& Sons, Ltd.: Chichester, UK, 2017; pp. 9-18. ISBN 9781119068747.

11. Reynolds, C.S.; Oliver, R.L.; Walsby, A.E. Cyanobacterial dominance: The role of buoyancy regulation in dynamic lake environments. N. Z. J. Mar. Freshw. Res. 1987, 21, 379-390. [CrossRef]

12. Schmidt, J.R.; Wilhelm, S.W.; Boyer, G.L. The fate of microcystins in the environment and challenges for monitoring. Toxins 2014, 6, 3354-3387. [CrossRef] [PubMed]

13. Svircev, Z.; Drobac, D.; Tokodi, N.; Mijovic, B.; Codd, G.A.; Meriluoto, J. Toxicology of microcystins with reference to cases of human intoxications and epidemiological investigations of exposures to cyanobacteria and cyanotoxins. Arch. Toxicol. 2017, 91, 621-650. [CrossRef] [PubMed]

14. Okello, W.; Kurmayer, R. Seasonal development of cyanobacteria and microcystin production in Ugandan freshwater lakes. Lakes Reserv. Res. Manag. 2011, 16, 123-135. [CrossRef]

15. Okello, W.; Portmann, C.; Erhard, M.; Gademann, K.; Kurmayer, R. Occurrence of microcystin-producing cyanobacteria in Ugandan freshwater habitats. Environ. Toxicol. 2010, 25, 367-380. [CrossRef] [PubMed]

16. Zhang, D.; Xie, P.; Liu, Y.; Qiu, T. Transfer, distribution and bioaccumulation of microcystins in the aquatic food web in Lake Taihu, China, with potential risks to human health. Sci. Total Environ. 2009, 407, 2191-2199. [CrossRef] [PubMed]

17. Sotton, B.; Guillard, J.; Anneville, O.; Maréchal, M.; Savichtcheva, O.; Domaizon, I. Trophic transfer of microcystins through the lake pelagic food web: Evidence for the role of zooplankton as a vector in fish contamination. Sci. Total Environ. 2014, 466, 152-163. [CrossRef] [PubMed]

18. Wood, J.D.; Franklin, R.B.; Garman, G.; McIninch, S.; Porter, A.J.; Bukaveckas, P.A. Exposure to the cyanotoxin microcystin arising from interspecific differences in feeding habits among fish and shellfish in the James River Estuary, Virginia. Environ. Sci. Technol. 2014, 48, 5194-5202. [CrossRef] [PubMed]

19. Semyalo, R.; Rohrlack, T.; Naggawa, C.; Nyakairu, G.W. Microcystin concentrations in Nile Tilapia (Oreochromis niloticus) caught from Murchison Bay, Lake Victoria and Lake Mburo: Uganda. Hydrobiologia 2010, 638, 235-244. [CrossRef]

20. Ibelings, B.W.; Chorus, I. Accumulation of cyanobacterial toxins in freshwater "seafood" and its consequences for public health: A review. Environ. Pollut. 2007, 150, 177-192. [CrossRef] [PubMed]

21. Semyalo, R.; Rohrlack, T.; Kayiira, D.; Kizito, Y.S.; Byarujali, S.; Nyakairu, G.; Larsson, P. On the diet of Nile tilapia in two eutrophic tropical lakes containing toxin producing cyanobacteria. Limnologica 2011, 41, 30-36. [CrossRef]

22. Nyakairu, G.W.; Nagawa, C.B.; Mbabazi, J. Assessment of cyanobacteria toxins in freshwater fish: A case study of Murchison Bay (Lake Victoria) and Lake Mburo, Uganda. Toxicon 2010, 55, 939-946. [CrossRef] [PubMed]

23. Poste, A.E.; Hecky, R.E.; Guildford, S.J. Evaluating microcystin exposure risk through fish consumption. Environ. Sci. Technol. 2011, 45, 5806-5811. [CrossRef] [PubMed]

24. World Health Organization. Guidelines for Drinking-Water Quality. Fourth Edition Incorporating the First Addendum; WHO: Geneva, Switzerland, 2017; p. 541. ISBN 978-92-4-154995-0.

25. Sharpe, D.M.; Wandera, S.B.; Chapman, L.J. Life history change in response to fishing and an introduced predator in the East African cyprinid Rastrineobola argentea. Evol. Appl. 2012, 5, 677-693. [CrossRef] [PubMed]

26. Abila, R.O. Assessment of fisheries products values along Kenya's export marketing chain. In FAO Fisheries Technical Report; No. 819; Food and Agriculture Organization of the United Nations: Rome, Italy, 2007; p. 262.

27. Wangechi, K.S.; Muigai, A.W.T.; Ouma, S.O. The Impact of evolution and socio-economics of commercially exploited fish stock: A Review on Rastrineobola argentea in Lake Victoria. J. Food Secur. 2015, 3, 82-86.

28. Alexander, R.; Imberger, J. Phytoplankton patchiness in Winam Gulf, Lake Victoria: A study using principal component analysis of in situ fluorescent excitation spectra. Freshw. Biol. 2013, 58, 275-291. [CrossRef] 
29. Okely, P.; Imberger, J.; Antenucci, P.J. Processes affecting horizontal mixing and dispersion in Winam Gulf, Lake Victoria. Limnol. Oceanogr. 2010, 55, 1865-1880. [CrossRef]

30. Gikuma-Njuru, P.; Hecky, R.E. Nutrient concentrations in Nyanza Gulf, Lake Victoria, Kenya: Light limits algal demand and abundance. Hydrobiologia 2005, 534, 131-140. [CrossRef]

31. Ishikawa, K.; Kumagai, M.; Vincent, W.F.; Tsujimura, S.; Nakahara, H. Transport and accumulation of bloom-forming cyanobacteria in a large, mid-latitude lake: The gyre-Microcystis hypothesis. Limnology 2002, 3, 87-96. [CrossRef]

32. Khisa, P.; Romero, J.R.; Imberger, J.; Ewing, T.; Antenucci, J.; Njuguna, H.; Okungu, J. The effect of the Mbita Causeway on water currents in the region of Rusinga Channel, Winam Gulf, Lake Victoria: A 3D modelling study with ELCOM. In Proceedings of the 11th World Lakes Conference, Nairobi, Kenya, 31 October-4 November 2005; Odada, E.O., Olago, D.O., Ochola, W., Ntiba, M., Wandiga, S., Gichuki, N., Oyieke, H., Eds.; Ministry of Water and Irrigation: Nairobi, Kenya, 2005; pp. 74-78.

33. Kurmayer, R.; Christiansen, G.; Chorus, I. The abundance of microcystin-producing genotypes correlates positively with colony size in Microcystis and determines its microcystin net production in Lake Wannsee. Appl. Environ. Microbiol. 2003, 69, 787-795. [CrossRef] [PubMed]

34. Kurmayer, R.; Dittmann, E.; Fastner, J.; Chorus, I. Diversity of microcystin genes within a population of the toxic cyanobacterium Microcystis. In Lake Wannsee (Berlin, Germany). Microb. Ecol. 2002, 43, 107-118. [CrossRef] [PubMed]

35. Graham, J.L.; Jones, J.R. Microcystin distribution in physical size class separations of natural plankton communities. Lake Reserv. Manag. 2007, 23, 161-168. [CrossRef]

36. Wang, X.; Sun, M.; Xie, M.; Liu, M.; Luo, L.; Li, P.; Kong, F. Differences in microcystin production and genotype composition among Microcystis colonies of different sizes in Lake Taihu. Water Res. 2013, 47, 5659-5669. [CrossRef] [PubMed]

37. Testai, E.; Buratti, F.M.; Funari, E.; Manganelli, M.; Vichi, S.; Arnich, N.; Biré, R.; Fessard, V.; Sialehaamoa, A. Review and analysis of occurrence, exposure and toxicity of cyanobacteria toxins in food. EFSA Support. Publ. 2016, 13, 998E. [CrossRef]

38. Cadel-Six, S.; Moyenga, D.; Magny, S.; Trotereau, S.; Edery, M.; Krys, S. Detection of free and covalently bound microcystins in different tissues (liver, intestines, gills, and muscles) of rainbow trout (Oncorhynchus mykiss) by liquid chromatography-tandem mass spectrometry: Method Characterization. Environ. Pollut. 2014, 185, 333-339. [CrossRef] [PubMed]

39. Smith, J.L.; Schulz, K.L.; Zimba, P.V.; Boyer, G.L. Possible mechanism for the foodweb transfer of covalently bound microcystins. Ecotoxicol. Environ. Saf. 2010, 73, 757-761. [CrossRef] [PubMed]

40. Schmidt, J.R.; Shaskus, M.; Estenik, J.F.; Oesch, C.; Khidekel, R.; Boyer, G.L. Variations in the microcystin content of different fish species collected from a eutrophic lake. Toxins 2013, 5, 992-1009. [CrossRef] [PubMed]

41. Isumbisho, M.; Petit, P.; Gashagaza, J.B.; Moreau, J. The feeding habit of the Cyprinidae Rastrineobola argentea in its new habitat, Lakes Bulera and Ruhondo, two Rwandan lakes (Eastern Africa). Knowl. Manag. Aquat. Ecosyst. 2011. [CrossRef]

42. Lawton, L.A.; Robertson, P.K.J. Physico-chemical treatment methods for the removal of microcystins (cyanobacterial hepatotoxins) from potable waters. Chem. Soc. Rev. 1999, 28, 217-224. [CrossRef]

43. Jacobs, L.C.V.; Peralta-Zamora, P.; Campos, F.R.; Pontarolo, R. Photocatalytic degradation of microcystin-LR in aqueous solutions. Chemosphere 2013, 90, 1552-1557. [CrossRef] [PubMed]

44. International Organization for Standardization. Water Quality-Measurement of Biochemical Parameters_Spectrometric Determination of the Chlorophyll-A Concentration; ISO 10260; ISO: Geneve, Switzerland, 1992.

45. Wetzel, R.G.; Likens, G.E. Limnological Analyses, 3rd ed.; Springer: New York, NY, USA, 2000; p. 429. ISBN 978-1-4757-3250-4.

46. Talling, J.F. The phytoplankton of Lake Victoria (East Africa). Arch. Hydrobiol. Beih. Ergeb. Limnol. 1987, 25, 229-56.

47. Komárek, J.; Kling, H. Variation in six planktonic cyanophyte genera in Lake Victoria (East Africa). Algol. Stud. 1991, 61, 21-45.

48. Cronberg, G.; Annadotter, H. Manual on Aquatic Cyanobacteria; A Photo Guide and Synopsis of Their Toxicology; International Society for the Study of Harmful Algae (ISSHA) and United Nations Educational, Scientific and Cultural Organisation (UNESCO): Copenhagen, Denmark, 2006; p. 106. ISBN 8799082705. 
49. Lawton, L.; Marsalek, B.; Padisak, J.; Chorus, I. Determination of cyanobacteria in the laboratory. In Toxic Cyanobacteria in Water; A Guide to Their Public Health Consequences, Monitoring and Management; Chorus, I., Bartram, J., Eds.; WHO: London, UK, 1999; pp. 347-368. ISBN 0-419-23930-8.

50. Fastner, J.; Flieger, I.; Neumann, U. Optimised extraction of microcystins from field samples-A comparison of different solvents and procedures. Water Res. 1998, 32, 3177-3181. [CrossRef]

51. Wilson, A.E.; Gossiaux, D.C.; Höök, T.O.; Berry, J.P.; Landrum, P.F.; Dyble, J.; Guildford, S.J. Evaluation of the human health threat associated with the hepatotoxin microcystin in the muscle and liver tissues of yellow perch (Perca flavescens). Can. J. Fish. Aquat. Sci. 2008, 65, 1487-1497. [CrossRef]

52. Metcalf, J.S.; Hyenstrand, P.; Beattie, K.A.; Codd, G.A. Effects of physicochemical variables and cyanobacterial extracts on the immunoassay of microcystin-LR by two ELISA kits. J. Appl. Microbiol. 2000, 89, 532-538. [CrossRef] [PubMed]

53. An, J.; Carmichael, W.W. Use of a colorimetric protein phosphatase inhibition assay and enzyme linked immunosorbent assay for the study of microcystins and nodularins. Toxicon 1994, 32, 1495-1507. [CrossRef]

(C) 2018 by the authors. Licensee MDPI, Basel, Switzerland. This article is an open access article distributed under the terms and conditions of the Creative Commons Attribution (CC BY) license (http://creativecommons.org/licenses/by/4.0/). 